\title{
DETECTION OF EBV-DNA IN SERUM SAMPLES OF AN IMMUNOSUPPRESSED CHILD DURING A THREE YEARS FOLLOW-UP: ASSOCIATION OF CLINICAL AND PCR DATA WITH ACTIVE INFECTION
}

\author{
Thelma Suely OKAY, Gilda Maria Barbaro DEL NEGRO, Lídia YAMAMOTO \& Roberto RAIZ JÚNIOR
}

\begin{abstract}
SUMMARY
Twenty-four whole blood and serum samples were drawn from an eight year-old heart transplant child during a 36 months follow-up. EBV serology was positive for VCA-IgM and $\mathrm{IgG}$, and negative for EBNA-IgG at the age of five years old when the child presented with signs and symptoms suggestive of acute infectious mononucleosis. After 14 months, serological parameters were: positive VCA-IgG, EBNA-IgG and negative VCA-IgM. This serological pattern has been maintained since then even during episodes suggestive of EBV reactivation. PCR amplified a specific DNA fragment from the EBV gp220 (detection limit of 100 viral copies). All twenty-four whole blood samples yielded positive results by PCR, while 12 out of 24 serum samples were positive. We aimed at analyzing whether detection of EBV-DNA in serum samples by PCR was associated with overt disease as stated by the need of antiviral treatment and hospitalization. Statistical analysis showed agreement between the two parameters evidenced by the Kappa test (value 0.750 ; $\mathrm{p}<0.001$ ). We concluded that detection of EBV-DNA in serum samples of immunosuppressed patients might be used as a laboratory marker of active EBV disease when a Real-Time PCR or another quantitative method is not available.
\end{abstract}

KEYWORDS: EBV-PCR; EBV viral load; EBV reactivation; VCA antibodies.

\section{INTRODUCTION}

Epstein-Barr virus (EBV) is the etiological agent of infectious mononucleosis. Diagnosis of infectious mononucleosis is based on characteristic clinical features and either a positive heterophil antibody test or serology, both of which can be unreliable in young children ${ }^{3}$. Serological markers are based on detection of viral capsid (VCA), as well as early (EA) and nuclear antigens (NA). The presence of immunoglobulin $\mathrm{M}$ antibody raised to the capsid antigen in the absence of antibody to the nuclear antigen (EBNA) is suggestive of acute primary EBV infection because EBNA antibodies develop in late convalescence ${ }^{13}$. However, falsenegative results may occur as a consequence of the transient nature of the VCA-IgM response. Conversely, false-positive IgM reactions can occur due to the presence of auto-antibodies, or cross-reactions with other members of herpes virus family ${ }^{14}$. Differentiation of recent and past EBV infections is particularly difficult in young children and immunocompromised hosts due to a delayed production of EBNA antibodies $^{8}$. In these patients, EBV plays a significant role as a cofactor in the process of lymphoproliferative disorders such as Burkitt's disease, some $\mathrm{T}$ and B-cell lymphomas and nasopharyngeal carcinomas ${ }^{5,17,20}$. Immunosuppressive drugs such as Cyclosporine A and tacrolimus seem to act synergistically with EBV as tumor inducing factors ${ }^{6}$.

EBV reactivations have been diagnosed by serologic profiles that suggest virus replication. Serological responses, however, are delayed and do not necessarily indicate ongoing replicative activity. Besides, they are known to underestimate the frequency of asymptomatic EBV reactivations ${ }^{15}$ which can be of clinical importance in immunocompromised patients.

The Polymerase Chain Reaction (PCR) has been used to detect EBV-DNA in serum samples of patients with primary and persistent EBV infection ${ }^{4,9}$. Quantitative amplification techniques have proved to be more reliable in clinical practice than qualitative ones to monitor and identify immunocompromised patients at risk to develop EBVrelated lymphoproliferative disease, for instance in transplant recipient subjects ${ }^{2}$. The most recent quantitative amplification method, RealTime PCR, constitutes the most suitable technique to evaluate EBV viral load with a maximum sensitivity and specificity. However, it is expensive, complex, and available in only a few centers ${ }^{18,22,23}$. To circumvent this problem, a conventional EBV-DNA PCR in serum samples with a detection limit of 100 viral copies per $\mu$ g of genomic DNA $^{21}$ might be useful to monitor EBV chronically infected immunocompromised patients at risk to develop recrudescent or severe disseminated disease because, in these patients, serological parameters are frequently incapable of predicting EBV reactivations.

\section{PATIENT AND METHODS}

PATIENT: We report the case of an eight-year-old boy submitted to a heart transplant surgery at the age of six months and since then, 


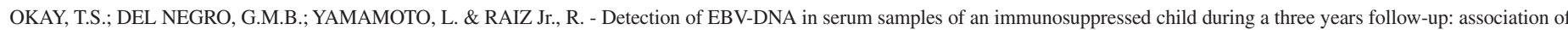
clinical and PCR data with active infection. Rev. Inst. Med. trop. S. Paulo, 47(2):99-102, 2005.

following immunosuppressive therapy with cyclosporine A, recently substituted for tacrolimus. At the age of five years, the patient presented with signs, symptoms, and laboratory data compatible with acute infectious mononucleosis. We have studied 24 clinical episodes corresponding either to periods in which the child presented with signs and symptoms suggestive of EBV reactivations or asymptomatic ones (ambulatory care). After the first episode of EBV disease at the age of five, the child has been sampled other 23 times in order to determine the presence of EBV-DNA in whole blood and serum samples and their association with clinical EBV reactivation. The boy has evolved with progressive deterioration of clinical conditions presenting with EBV relapses or reactivations. The boy was critically ill by the $25^{\text {th }}$ month of follow-up (late-onset of chronic transplant rejection and disseminated EBV disease), with an unexpected recovering after the $30^{\text {th }}$ month, being clinically stable since then.

SEROLOGY: IgG antibodies to VCA were determined by capture ELISA (Diasorin, Italy); VCA- IgG positive > $20 \mathrm{AU} / \mathrm{mL}$ and VCA-IgM positive (qualitative test). IgG to EBNA (nuclear antigen) was determined by ELISA (Sanofi Diagnostics Pasteur, France). The samples were classified as: acute EBV infection (positive for IgM and IgG to VCA but negative to IgG-EBNA; post-acute EBV infection or EBV carrier state (positive for IgG to VCA and IgG-EBNA but negative for IgM to VCA); EBV-seronegative individual (negative for the three serological markers). Tests were performed according to the instructions of manufacturers and also following the protocols described elsewhere ${ }^{1,9,10}$.

DNA EXTRACTION FROM WHOLE BLOOD: Peripheral blood leukocytes and serum samples were drawn twenty-four times during 24 clinical events, after informed consent of the child's mother. Two milliliters of whole blood samples were submitted to a rapid and cost-effective DNA extraction according to the protocol described elsewhere ${ }^{7}$. Briefly, $200 \mu \mathrm{L}$ of EDTA- whole blood were added to a $1.5 \mathrm{~mL}$ microtube containing $800 \mu \mathrm{L}$ of a $170 \mathrm{mM} \mathrm{NH}_{4} \mathrm{Cl}$ solution. After centrifugation, the supernatant was discarded and the cell pellet was re-suspended in $300 \mu \mathrm{L}$ of a $10 \mathrm{mM} \mathrm{NaCl} / \mathrm{EDTA}$ solution. After a second centrifugation, the supernatant was discarded and the cell pellet was re-suspended in $500 \mu \mathrm{L}$ of a $50 \mathrm{mM} \mathrm{NaOH}$ solution. Samples were incubated at $100{ }^{\circ} \mathrm{C}$ for five minutes and then recentrifuged. The DNA was contained within the supernatant liquid and its concentration estimated at $260 \mathrm{~nm}$ by UV spectrophotometry (Beckman, DU-70).

DNA EXTRACTION FROM SERUM SAMPLES: Serum and plasma samples are known to contain inhibitors of PCR which must be removed by DNA extraction techniques ${ }^{11,12,16}$. This is the reason why, in the present study, DNA was extracted from $200 \mu \mathrm{L}$ of serum using spin columms (QIAamp DNA Blood Mini kit, Qiagen, Valencia, CA), eluted in $50 \mu \mathrm{L}$ of AE buffer (Qiagen) previously treated with proteinase $\mathrm{K}(20 \mu \mathrm{g} / \mu \mathrm{L})$. Afterwards, serum DNA samples were stored at $-20{ }^{\circ} \mathrm{C}$ until needed. It is not possible to determine DNA concentration by UV spectrophotometry when DNA is obtained by means of this extraction kit so that we fixed the volume of serum samples at the beginning $(200 \mu \mathrm{L})$ and the volume of DNA sample to be used in amplifications $(20 \mu \mathrm{L})$.

POLYMERASE CHAIN REACTION: PCR assays were performed in $50 \mu \mathrm{L}$ of total volume containing either $20 \mu \mathrm{L}$ of genomic
DNA from whole blood samples (approximately $1 \mu \mathrm{g}$ of genomic DNA), or $20 \mu \mathrm{L}$ of DNA from serum samples (DNA concentration not determined), $100 \mathrm{mM}$ of Tris- $\mathrm{HCl}$ and $500 \mathrm{mM}$ of $\mathrm{KCl} ; 2.5$ units of Taq DNA polymerase (Amersham Biotech, USA), $200 \mu \mathrm{M}$ of dNTP (Invitrogen, USA), $1.5 \mathrm{mM}$ of $\mathrm{MgCl}_{2} ; 0.4 \mu \mathrm{M}$ of each EBV gp 220 primer: gp1 sense - 5'- GGC TGG TGT CAG CTG TGT TA - 3' and gp2-anti-sense 5' - CCT TAG GAG GAA CAA GTC CC -3' (synthesized by MWG Biotech). Samples were overlaid with $50 \mu \mathrm{L}$ of sterile mineral oil. An initial denaturation step of five minutes at $95{ }^{\circ} \mathrm{C}$ was followed by 40 cycles of 30 seconds at $95{ }^{\circ} \mathrm{C}, 30$ seconds at $57{ }^{\circ} \mathrm{C}$ and one minute at $72{ }^{\circ} \mathrm{C}$. A final extension time of five minutes at $72{ }^{\circ} \mathrm{C}$ ended the amplification (M.J. Research PT-150 minicycler). PCR products (239 bp) were detected in $2 \%$ ethidium bromide-stained agarose (Sigma, USA) gels ${ }^{21}$ in a horizontal electrophoresis apparatus (Horizon H58, Life Technologies, USA). DNA-PCR was performed to amplify a portion of the gene coding for the EBV gp220 with a detection limit of 100 viral copies. In each experiment, a negative control composed of either sterile water instead of genomic or serum human DNA, or DNA from a non infected individual was tested, as well as a positive control (EBV DNA from viral cultures).

\section{RESULTS}

In the present study we aimed at analyzing the association between EBV-DNA detection in serum samples and the occurrence of EBV reactivations in an immunosuppressed heart transplant child by means of a standard non quantitative PCR protocol which is able to detect 100 viral copies of a specific fragment from the EBV gp220 gene. Some of the PCR results are shown in Figure 1.

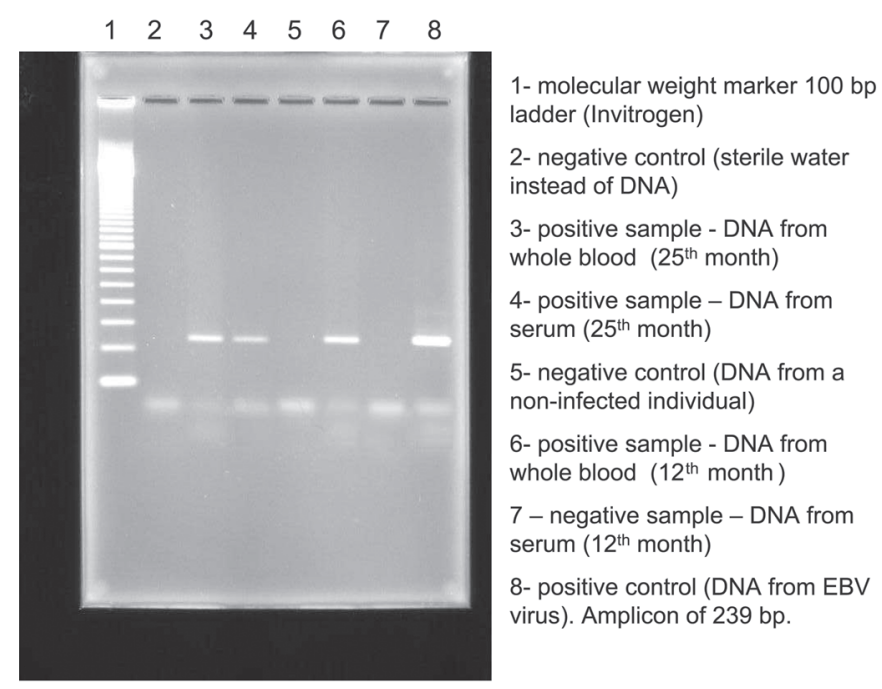

Fig. 1 - EBV-DNA amplification from whole blood and serum samples of the 8-year-old heart transplant patient. Lane 1: molecular weight marker 100 bp ladder (Invitrogen); lane 2: negative control (sterile water instead of DNA); lane 3: positive sample corresponding to DNA from whole blood ( $25^{\text {th }}$ month); lane 4 positive sample corresponding to DNA from serum sample ( $25^{\text {th }}$ month); lane 5: negative control corresponding to DNA from whole blood sample of a non-infected individual; lane 6: positive sample corresponding to DNA from whole blood (12 $2^{\text {th }}$ month); lane 7: negative sample corresponding to DNA from serum (12 $2^{\text {th }}$ month); lane 8: positive control corresponding to DNA from EBV virus (amplicon of 239 bp). 


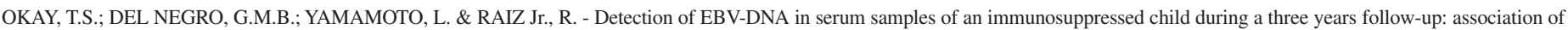
clinical and PCR data with active infection. Rev. Inst. Med. trop. S. Paulo, 47(2):99-102, 2005.

Table 1

Description of clinical and laboratory data (serum PCR results) of the 8-year-old heart transplant patient during the 36 months follow-up. The moment of blood

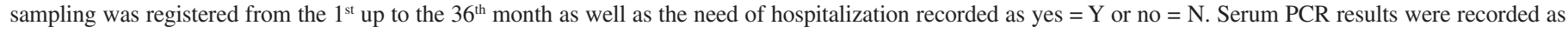
positive or negative (+ or -)

\begin{tabular}{|c|c|c|c|}
\hline $\begin{array}{l}\text { Month of } \\
\text { follow-up }\end{array}$ & $\begin{array}{c}\text { Need of } \\
\text { hospitalization }\end{array}$ & Serum PCR & Clinical status \\
\hline 1 & $\mathrm{Y}$ & + & $\begin{array}{l}\text { Acute infectious mononucleosis (lymphadenopathy, fever). Cyclosporine A + antibiotics }+ \\
\text { acyclovir }\end{array}$ \\
\hline $2 ; 3$ & $\mathrm{~N}$ & - & Stable. Ambulatory treatment. Cyclosporine A \\
\hline 4 & $\mathrm{Y}$ & + & Lymphadenopathy, fever, pneumonia. Antibiotics + acyclovir. Cyclosporine A \\
\hline $5 ; 8$ & $\mathrm{~N}$ & - & Stable. Ambulatory treatment. Cyclosporine A \\
\hline $9 ; 10$ & $\mathrm{Y}$ & + & Pharyngitis, lymphadenopathy, fever, myocarditis. Antibiotics + acyclovir. Cyclosporine A \\
\hline $11 ; 12 ; 14$ & $\mathrm{~N}$ & - & Stable. Ambulatory treatment. Cyclosporine A \\
\hline 17 & Y & + & Pharyngitis, lymphadenopathy, fever, myocarditis. Antibiotics + acyclovir. Cyclosporine A \\
\hline 18 & $\mathrm{~N}$ & - & Stable. Ambulatory treatment. Cyclosporine A \\
\hline 20 & Y & + & Lymphadenopathy, fever, pneumonia, myocarditis. Antibiotics + acyclovir. Cyclosporine A \\
\hline $21 ; 24$ & $\mathrm{~N}$ & - & Stable. Ambulatory treatment. Cyclosporine A \\
\hline $25 ; 26 ; 27 ; 28 ; 29$ & $\mathrm{Y}$ & + & $\begin{array}{l}\text { Cyclosporine substituted for tacrolimus. Lymphadenopathy, pneumonia, hepatomegaly, } \\
\text { jaundice, myocarditis, cardiac insufficiency, uveitis (EBV-DNA PCR positive in aqueous } \\
\text { humor). Broad spectrum antibiotics. }\end{array}$ \\
\hline $30 ; 34 ; 36$ & $\mathrm{~N}$ & - & Stable (day-care treatment). Asymptomatic. Tacrolimus \\
\hline
\end{tabular}

Initially, during the first episode of acute infectious mononucleosis at the age of five, the child presented with positive VCA-IgM and IgG, and negative EBNA-IgG (acute EBV infection profile). Fourteen months later, VCA-IgM became undetectable while VCA-IgG remained positive. At that time, EBNA-IgG began to be synthesized. This serologic pattern (positive VCA-IgG and EBNA-IgG and negative VCA$\operatorname{IgM}$ ) has been maintained since then until the $36^{\text {th }}$ month of followup, even during clinical episodes suggestive of EBV reactivations (postacute EBV infection or carrier state serological profile), thus restricting the use of serological parameters to control EBV reactivations.

All twenty-four whole blood DNA samples extracted from peripheral blood leukocytes were EBV-DNA positive. On the contrary, only twelve out of twenty-four serum samples were EBV-DNA positive. Some of the PCR results are shown in Figure 1. PCR-positive serum samples corresponded, in the majority of cases, to the ones obtained during hospitalization and life threatening episodes, just before acyclovir treatment was initiated. The $25^{\text {th }}$ serum sample corresponded to a prolonged and critical hospital staying. At that time, along with the peripheral blood leukocyte and the serum sample, EBV-DNA was also detected in the eye (aqueous humor). Conversely, the other twelve EBV-DNA negative serum samples were drawn either during ambulatory follow-up, or at the end of antibiotics and antiviral therapy, and in most of the episodes the patient was doing well. Clinical features, laboratory data as well as therapeutic measures adopted during the 36 months of follow-up were summarized in Table 1.

Statistical analysis enabled us to measure the agreement of the two parameters, i.e., positive EBV-DNA-PCR in serum samples and the need of hospitalization and antiviral treatment. For that, we applied the Kappa test (SPSS 12.0 for windows) which has shown a value of $0.750(\mathrm{p}<0.001)$.

\section{DISCUSSION}

The present study has found positive amplifications in all 24 DNA samples extracted from whole blood samples. These results were expected because the patient is chronically infected and has followed immunosuppression with cyclosporine $\mathrm{A}$ and latter with tacrolimus. In this group of patients, effective clearance of EBV is not the rule ${ }^{8}$.

A number of studies have used serum samples to evaluate the association of EBV activity with the onset of lymphoproliferative diseases in immunosuppressed patients ${ }^{5,20}$. Other studies have pointed out the correlation between positive EBV-DNA in serum samples and the activity of disease before and after the advent of Real-Time PCR and other quantitative techniques ${ }^{1,2,17,22}$. However, some authors have reported that serum is an undesirable clinical specimen for EBV DNA load monitoring because it omits the presence of cell-associated virus, and uncontrolled cell lysis may give irreproducible results or overestimation of the DNA load $^{19}$. Even so, we detected EBV-DNA in all 24 whole blood samples and in only 12 out of 24 serum samples in the present study. Positive PCR tests were found among samples from episodes in which the patient was hospitalized whereas negative PCR results corresponded mostly to the occasions in which the child was clinically stable.

According to the analysis performed by means of the Kappa test there is a significant statistical agreement between EBV disease activity (in the present study represented by the need of hospitalization and antiviral treatment) and the finding of EBV-DNA in serum samples by PCR (value $0.75 ; \mathrm{p}<0.001$ ).

The data presented herewith, although based on the study of 24 clinical episodes of a single immunosuppressed and EBV chronically infected patient, suggest that a rapid and cost-effective EBV-DNA 


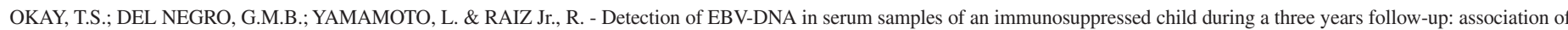
clinical and PCR data with active infection. Rev. Inst. Med. trop. S. Paulo, 47(2):99-102, 2005.

detection in serum samples (cell-free EBV virus) by PCR with a detection limit of 100 viral copies per $\mu \mathrm{g}$ of human DNA might be used as a marker of disease activity in chronically infected immunocompromised patients when a Real-Time PCR or another reliable quantitative amplification technique is not available.

In conclusion, there was a statistically significant association between EBV-DNA detection in serum samples and the occurrence of overt disease as stated by clinical signs and symptoms, the need of hospitalization and antiviral therapy.

\section{RESUMO}

\section{Detecção de EBV-DNA em amostras de soro de criança imunodeprimida durante três anos de seguimento: associação de dados clínicos e de PCR com a infecção ativa}

Vinte e quatro amostras de sangue total e de soro foram colhidas durante seguimento por 36 meses de criança de oito anos de idade, imunodeprimida devido a transplante cardíaco. O paciente apresentou VCA-IgG e IgM positivos e EBNA-IgG negativo aos cinco anos de idade quando foi diagnosticada mononucleose infecciosa. Quatorze meses depois o VCA-IgG e o EBNA-IgG eram positivos e o VCA-IgM negativo. Este padrão sorológico persiste desde aquela época mesmo durante episódios sugestivos de reativação. As amostras de sangue total e de soro foram analisadas pela Reação em Cadeia da Polimerase (PCR) que amplificou fragmento oriundo da gp220 do EBV (detecção de 100 cópias virais). Todas as 24 amostras de sangue total e 12 amostras de soro foram positivas por PCR. Com o objetivo de verificar se a detecção de DNA do EBV em soro estaria associada à reativação da doença, os resultados de PCR foram analisados em relação à necessidade de hospitalização e uso de anti-viral. O teste de Kappa mostrou que existe concordância entre a presença de DNA do EBV em soro e a necessidade de hospitalização e tratamento com anti-virais (valor de 0,$750 ; \mathrm{p}<$ 0,001). Concluímos que a detecção de DNA do EBV em amostras de soro de pacientes imunosuprimidos poderia ser usada como marcador laboratorial de atividade da infecção quando técnicas quantitativas de amplificação não estiverem disponíveis.

\section{REFERENCES}

1. BERGER, C.; DAY, P.; MEIER, G. et al. - Dynamics of Epstein-Barr virus DNA levels in serum during EBV-associated disease. J. med. Virol., 64: 505-512, 2001.

2. CAMPE, H.; JAEGER, G.; ABOU-AJRAM, C. et al. - Serial detection of Epstein-Barr virus DNA in sera and peripheral blood leukocyte samples of pediatric renal allograph recipients with persistent mononucleosis-like symptoms defines patients at risk to develop post-transplant lymphoproliferative disease. Pediat. Transplant., 7: 46-52, 2003.

3. CHAN, K.H.; LUO, R.X.; CHEN, H.L. et al. - Development and evaluation of an EpsteinBarr virus (EBV) immunoglobulin $\mathrm{M}$ enzyme-linked immunosorbent assay based on the 18-kilodalton matrix protein for diagnosis of primary EBV infection. J. clin. Microbiol., 36: 3359-3361, 1998.

4. CHAN, K.H.; NG, M.H.; SETO, W.H. \& PEIRIS, J.S.M. - Epstein-Barr virus (EBV) DNA in sera of patients with primary EBV infection. J. clin. Microbiol., 39: 41524154, 2001.

5. CHAN, K.C.A.; ZHANG, J.; CHAN, A.T.C. et al. - Molecular characterization of circulating EBV DNA in the plasma of nasopharyngeal carcinoma and lymphoma patients. Cancer Res., 63: 2028-2032, 2003.
6. CHAND, D.H.; SOUTHERLAND, S.M. \& CUNNINGHAM $3^{\text {rd }}$, J. R. - Tacrolimus: the good, the bad, and the ugly. Pediat. Transplant., 5: 32-36, 2001.

7. FERRIE, R.M.; SCHWARTZ, M.J.; ROBERTSON, N.H. et al. - Development, multiplexing and application of ARMS tests for common mutations in the CFTR gene. Amer. J. hum. Genet., 51: 251-262, 1992.

8. GRAY, J.J. - Avidity of EBV VCA-specific IgG antibodies: distinction between recent primary infection, past infection and reactivation. J. virol. Meth., 52: 95-104, 1995.

9. HAQUE, T.; THOMAS, J.A.; PARRAT, R. et al. - Prospective study in heart and lung transplant recipients correlating persistent Epstein-Barr virus infection with clinical events. Transplantation, 64: 1028-1034, 1997.

10. IKUTA, K.; SAIGA, K.; DEGUCHI, M. \& SAIRENJI, T. - Epstein-Barr virus DNA is detected in peripheral blood mononuclear cells of EBV-seronegative infants with infectious mononucleosis-like symptoms. Virus Genes, 26: 165-173, 2003.

11. KRAMVIS, A.; BUKOFZER, S. \& KEW, M.C. - Comparison of hepatitis B virus DNA extractions from serum by the QIAamp blood kit, Gene Releaser, and the PhenolChloroform Method. J. clin. Microbiol., 34 : 2731-2733, 1996.

12. KLEIN, A.; BARSUK, R.; DAGAN, S. et al. - Comparison of methods for extraction of nucleic acid from hemolytic serum for PCR amplification of hepatitis B virus DNA sequences. J. clin. Microbiol., 35: 1897-1899, 1997.

13. LENNETTE, E.T. - Epstein-Barr virus. In: LENNETTE, E.H. Laboratory diagnosis of viral infections. New York, Marcel Dekker, 1992. p. 365-380.

14. MATHESON, B.A.; CHISHOLM, S.M. \& HO-YEN, D.O. - Assessment of rapid ELISA test for detection of Epstein-Barr virus infection. J. clin. Path., 43: 691-693, 1990.

15. MAURMANN, S.; FRICKE, L.; WAGNER, H-J. et al. - Molecular parameters for precise diagnosis of asymptomatic Epstein-Barr virus reactivation in healthy carriers. J. clin. Microbiol., 41: 5419-5428, 2003.

16. MOURITSEN, C.L.; WITTWER, C.T.; REED, G. et al. - Detection of Epstein-Barr viral DNA in serum using rapid-cycle PCR. Biochem. Molec. Med., 60: 161-168, 1997.

17. NGAN, R.K.C.; YIP, T.T.C.; CHENG, W-W. et al. - Circulating Epstein-Barr virus DNA in serum of patients with lymphoepithelioma-like carcinoma of the lung: a potential surrogate marker for monitoring disease. Clin. Cancer Res., 8: 986-994, 2002.

18. PITETTI, R.D.; LAUS, S. \& WADOWSKY, R.M. - Clinical evaluation of a quantitative real time polymerase chain reaction assay for diagnosis of primary Epstein-Barr virus infection in children. Pediat. infect. Dis. J., 22: 736-739, 2003.

19. STEVENS, S.J.C.; PRONK, I. \& MIDDELDORP, J.M. - Toward standardization of Epstein-Barr virus DNA load monitoring: unfractionated whole blood as preferred clinical specimen. J. clin. Microbiol., 39: 1211-1216, 2001.

20. SHAO, J-Y.; LI, Y-H.; GAO, H-Y. et al. - Comparison of plasma Epstein-Barr virus (EBV) DNA levels and serum EBV immunoglobulin A/virus capsid antigen antibody titers in patients with nasopharyngeal carcinoma. Cancer, 100: 1162-1170, 2004.

21. TELENTI, A. - PCR detection and typing of Epstein-Barr virus. In: PERSING, D.H.; SMITH, T.F.; TENOVER, F.C. \& WHITE, T.J. Diagnostic molecular Microbiology. Washington, American Society for Microbiology, 1993. p. 344-349.

22. WAGNER, H-J.; FISCHER, L.; WOLFRAM, J. et al. - Longitudinal analysis of EpsteinBarr viral load in plasma and peripheral blood mononuclear cells of transplanted patients by real-time polymerase chain reaction. Transplantation, 74: 656-664, 2002.

23. ZINGG, W.; BOSSART, W.; BERLI, E. \& NADAL, D. - Detection and quantitation of cell-free Epstein-Barr virus by polymerase chain reaction and subsequent DNA enzyme immunoassay. J. virol. Meth., 79: 141-148, 1999.

Received: 13 September 2004

Accepted: 3 January 2005 